\title{
Kinetics of specific humoral immune response of mice infected with low doses of Trichinella spiralis, T. britovi, and T. pseudospiralis larvae
}

\author{
E. DVOROŽŇÁKOVÁ ${ }^{1}$, Z. HURNÍKOVÁ ${ }^{1}$, M. KOŁODZIEJ-SOBOCIŃSKA ${ }^{2}$
}

\author{
${ }^{1}$ Parasitological Institute SAS, Hlinkova 3, 04001 Košice, Slovak Republic, E-mail: dvoroz@saske.sk; \\ ${ }^{2}$ Institute of Parasitology PAS, Twarda str 51/55, 00818 Warsaw, Poland
}

\begin{abstract}
Summary
The specific humoral immune response of the host (mouse) to the infection with low doses of larvae of encapsulating (Trichinella spiralis, T. britovi) and non-encapsulating ( $T$. pseudospiralis) species was studied. Mice were experimentally infected with 10 muscle larvae of the parasite to simulate natural conditions of the infection in rodents, important reservoirs of trichinellosis. The low infective dose of T. spiralis and T. britovi did not evoke an increased specific IgM response, which is typical for the acute infection. Only T. pseudospiralis induced a higher specific IgM level in the intestinal phase of the infection, till day 30 p.i. The low infective dose of $T$. spiralis larvae stimulated a specific $\mathrm{IgG}_{1}$ production from day 20 p.i. with a strong increase on day 45 p.i., but T. britovi infection on day 60 p.i. Specific $\operatorname{IgG}_{1}$ antibodies were not detected in $T$. pseudospiralis infection. The production of $\operatorname{IgG}_{2 \mathrm{a}}$ and $\mathrm{IgG}_{2 b}$ antibodies was again earlier and more expressive in T. spiralis infection from day 45 p.i., in contrast to T. britovi, where these antibodies were increased on day 60 p.i. Only $\mathrm{IgG}_{2 \mathrm{~b}}$ isotype was detected in T. pseudospiralis infection on days 45 and 60 p.i., however in very low values in comparison with encapsulating species.

Results conclude the low infective dose of T. spiralis, $T$. britovi, and $T$. pseudospiralis induced a late seroconversion in infected mice. T. spiralis caused earlier and more intensive specific antibody response, from day 45 p.i, when antigens from newborn and muscle larvae were accumulated, on the contrary to T. britovi and T. pseudospiralis, which induced specific antibody response from day 60 p.i.
\end{abstract}

Keywords: low infection, antibodies; Trichinella spiralis; T. britovi; T. pseudospiralis

\section{Introduction}

Trichinella spp. is the intestinal nematode parasite with worldwide distribution and which causes trichinellosis - a serious zoonosis. (Miterpáková et al., 2009; Paraličová et al., 2009). At present, the genus Trichinella comprises five encapsulating (T. spiralis, T. nativa, T. britovi, T. nelsoni and $T$. murrelli) and three non-encapsulating species $(T$. pseudospiralis, T. papuae and T. zimbabwensis)(Morgan, 2000). The characteristics of these species are based on biological, biochemical and genetic criteria. Species variation in infectivity and immunogenicity is very important (Bolas-Fernández, 2003). Experimental studies demonstrated significant differences in infectivity of well characterised domestic and sylvatic Trichinella genotypes and the dependence of infective dose on the effectiveness of infection (Kapel \& Gamble, 2000; Cui et al., 2006; Reiterová et al., 2009). Infectivity of Trichinella species is also determined by the immune status of the host.

Larval cuticular fragments (Bruschi et al., 1992) and metabolites stimulate both specific and non-specific defense reactions during trichinellosis. Trichinella spp. infection induces $\mathrm{T}$ cell dependent inflammatory response of the host in which Th2 immune response is activated during the intestinal infection (Wakelin \& Goyal, 1996) and Th1 response is suppressed (Hogaboam et al., 1996). The muscle infection with $T$. spiralis elicits a focal cellular immune response. Parasites survive in nurse cells in close association with macrophages, CD8+ and CD4+ T lymphocytes, and $\mathrm{B}$ lymphocytes (Beiting et al., 2004). B lymphocytes secreting antibodies, particularly IgG and IgE, may lead to an effective antibody-dependent cell mediated cytotoxic reaction against $T$. spiralis newborn larvae (Moloney \& Denham, 1979; Wang \& Bell, 1988). The earlier specific antibodies are bound to Trichinella antigens and form immune complexes, which are present in infected host at the beginning of the infection (Dziemian \& Machnicka, 2000; Feldmeier et al., 1987). The protective isotypes $\operatorname{IgG}_{1}$ and $\mathrm{IgG}_{2}$ are involved in the inflammatory response. An elevation of $\mathrm{IgG}_{1}$ accompanies the muscle phase of infection (Doligalska, 2000) and newborn larve are more sensitive in vitro to 
$\mathrm{IgG}_{1}$ in antibody-dependent cellular cytotoxicity (Moskwa, 1999). Antibodies significantly participate in Trichinella entrapment and rapid expulsion of infective larvae $\mathrm{L} 1$, reduce adult worm fecundity and kill newborn larvae (Appleton \& Usack, 1993). The consistent release of circulating antigens by the larvae plays a major role in sustaining the host immune response until the calcification of the parasites ( $\mathrm{Li}$ et al., 1999). Circulating antigens are present in plasma and urine of infected organisms about 30 days after the infection (Machnicka et al., 2001; Kolodziej-Sobocińska et al., 2006). Specific antibodies remain detectable for a very long time after the infection. Polyclonal lymphocyte activation of T-cells, but particularly B-cells, is responsible for the high levels of immunoglobulines $\operatorname{IgG}, \operatorname{IgM}$, and $\operatorname{IgE}$ observed in infected animals and humans (Murrel \& Bruschi, 1994).

Specific anti-Trichinella IgM antibodies are first found, during second week of the infection ( $\mathrm{Li} \& \mathrm{Ko}, 2001$; Kolodziej-Sobocińska et al., 2006). Specific IgG antibodies were found also 6 or 8 months after infection, even after 3 years (Dziemian \& Machnicka, 2000; KolodziejSobocińska et al., 2006; Morales et al., 2002). Stimulation of ES antigens production by larvae and their penetration through the capsules (Pritchard, 1985) as well as degradation of larvae by inflammatory cells (Candolfi et al., 1989) explains the long-lasting presence of IgM, IgG antibodies. Immunoglobulines $\operatorname{IgG}_{1}$ represent Th2-cell activation and $\mathrm{IgG}_{2}$ antibodies reflect Th1 response (Else \& Finkelman, 1998). A significant elevation of $\operatorname{IgG}_{1}$ is often observed in trichinellosis (Li \& Ko, 2001; Kolodziej-Sobocińska et al., 2006). Both $\operatorname{IgG}_{1}$ and $\mathrm{IgG}_{2}$ are responsible for antilarval activity of peritoneal eosinophils that are involved in the inflammatory response (Doligalska, 2000).

Potential differences in a development of the host immune response to different Trichinella species and host-parasite interactions are rarely studied under in vivo conditions. Kapel and Gamble (2000) observed variances in the infectivity and antibody responses of pigs to domestic and sylvatic Trichinella spp. after a high infective dose. Andrade et al. (2007) described interspecies results from in vitro study, where the differences in NO production of macrophages after stimulation with L1 antigens from encapsulated and non-encapsulated trichinellas were demonstrated. Immunochemical variety of larval $T$. spiralis and $T$. pseudospiralis antigens had been confirmed by Turčeková et al. (1997).

The aim of this study was to observe the dynamics of specific antibody response in mice after the infection with low doses of larvae of encapsulating (Trichinella spiralis, $T$. britovi) and non-encapsulating (T. pseudospiralis) species.

\section{Materials and methods}

The experiment was carried out on male BALB/c mice $(\mathrm{n}=$ 144) weighting $20-25 \mathrm{~g}$. Mice were kept under a 12-h light/dark regime at room temperature $\left(22-24^{\circ} \mathrm{C}\right)$ and $56 \%$ humidity on a commercial diet and water. The experimental protocol was approved by the Parasitological Institute Animal Care Commitee. Animals were divided randomly into four groups as folows: Group $1(n=24)$ was uninfected and untreated (control), mice in Group $2(\mathrm{n}=40)$ were infected per os with $10 \mathrm{~T}$. spiralis larvae per mouse on day 0 of the experiment. Mice in Groups $3(n=40)$ and 4 $(\mathrm{n}=40)$ were infected per os with $10 \mathrm{~T}$. britovi and $T$. pseudospiralis larvae per mouse, respectively.

Samples of blood were obtained on days: 0 (prior infection), 5, 10, 15, 20, 30, 45 and 60 post infection (p.i.) from all groups, from 5 infected and 3 uninfected mice. The blood was centrifuged at $3000 \mathrm{~g}$ for 10 minutes and serum samples were stored at $-20{ }^{\circ} \mathrm{C}$ until the examination.

\section{The infective larvae Trichinella spp.:}

The reference isolates of Trichinella spiralis (ISS 004), $T$. britovi (ISS 1088) and T. pseudospiralis (ISS 013) (obtained and assigned codes from the Trichinella Reference Centre in Rome), maintained by serial passage in ICR mice at the Parasitological Institute SAS, were used for the infection. Larvae were released by artificial digestion (1\% pepsin, $1 \% \mathrm{HCl}$ for $4 \mathrm{~h}$ at $37^{\circ} \mathrm{C}$ ) of tissue following the standard protocol and kept saline solution until inoculation of experimental mice.

Detection of specific antibody production by iELISA:

Specific Trichinella spp. antibodies in serum were detected by indirect ELISA according to Reiterová et al. (1999). Somatic antigens (T. spiralis, T. britovi, T. pseudospiralis) diluted at $2 \mu \mathrm{g} / \mathrm{ml}$ carbonate buffer ( $\mathrm{pH} 9.6$ ) were bound to the microtitrate plates (Nunc, Denmark) overnight at $4{ }^{\circ} \mathrm{C}$. After triple washing of wells with phosphate buffered saline (PBS, $\mathrm{pH}=7.2$ ) with $0.5 \%$ Tween 20 (PBS-T) nonspecific bonds were blocked with by $0.5 \%$ skimmed milk PBS after 1 hour incubation at room temperature. After triple washing with PBS-T the serum samples and conjugates were added step by step for 1-hour incubation at 37 ${ }^{\circ} \mathrm{C}$. Sera were diluted 1:100 in PBS-T. Anti-mouse horseradish peroxidase conjugates (all Sigma-Aldrich, Germany) were diluted: $\operatorname{IgM}(1: 2000), \operatorname{IgG}_{1}$ (1:2000), $\operatorname{IgG}_{2 \mathrm{a}}$ $(1: 500)$ and $\operatorname{IgG}_{2 b}(1: 500)$. The substrate o-phenylene diamine (Sigma-Aldrich, Germany) at $0.05 \mathrm{~mol} / \mathrm{l}$ in citrate buffer ( $\mathrm{pH} 4.7$ ) with $0.005 \% \mathrm{H}_{2} \mathrm{O}_{2}$ was used for a visual reaction. The reaction was stopped by $1 \mathrm{M} \mathrm{H}_{2} \mathrm{SO}_{4}$ after 20 minutes incubation at room temperature in the dark. Plates were measured for the optical density at $490 \mathrm{~nm}$ (Revelation Quicklink, Opsys MR, Dynex Technologies, USA).

\section{Intestinal worm burdens:}

The intestinal phase of infection was investigated on days $5,10,15$ and 20 p.i. Small intestine was cut into $5-10 \mathrm{~cm}$ long pieces, placed into a sieve and incubated in conical pilsner glasses in $37{ }^{\circ} \mathrm{C} \mathrm{NaCl}(0.9 \%$ saline $)$ overnight. After incubation, gut pieces were discarded and the sediment was counted under stereomicroscope at $60 \mathrm{x}$ magnification.

Isolation of muscle larvae:

The muscle phase of infection was examined on days 20, 30, 45 and 60 p.i. Whole eviscerated carcasses were 


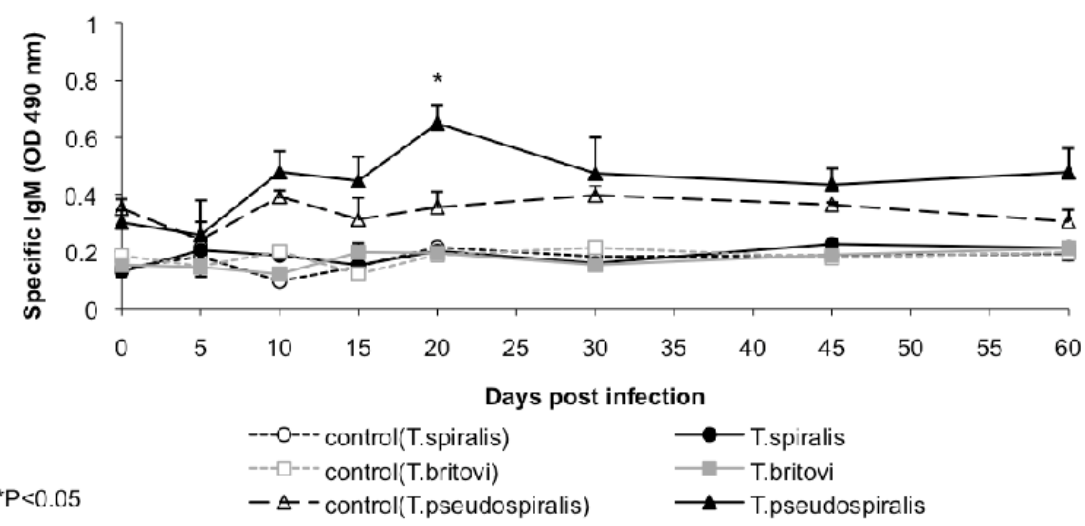

Fig. 1. Specific antibodies IgM in mice infected with 10 larvae of Trichinella spiralis, T. britovi and T. pseudospiralis.

$*(\mathrm{P}<0.05)$ statistically significant from control uninfected mice.

minced and artificially digested $(1 \%$ pepsin, $1 \% \mathrm{HCl}$ for $4 \mathrm{~h}$ at $37^{\circ} \mathrm{C}$; both Sigma-Aldrich, Germany) according to Kapel and Gamble (2000). Samples were allowed to settle for $20 \mathrm{~min}$ before the supernatant was discard and the sediment was poured through a $180 \mu \mathrm{m}$ sieve into a conical glass and washed with tap water. The sediment was finally transferred to a gridded Petri dished and counted using a stereomicroscope at $40 \mathrm{x}$ magnification. Depending on the density of larvae either a sub-sample or the whole sample was counted.

\section{Statistical evaluation:}

Statistical differences were assessed using one-way ANOVA, followed by post hoc Tukey's test (a value of $\mathrm{P}<$ 0.05 was considered significant), which allowed comparison between each two groups at each time point. The analyses were performed using the Statistica 6.O (Stat Soft, Tulsa, USA) statistical package.

\section{Results}

Dynamics of specific immunoglobulines $\operatorname{Ig} M, \operatorname{Ig} G_{1}, \operatorname{Ig} G_{2 a}$ $\operatorname{Ig} G_{2 b}$ (Figs. 1 - 4)
The low infective dose of 10 larvae of Trichinella spiralis and $T$. britovi did not induce an increase in specific IgM antibody response, no seroconversion was observed in comparison with the control. However, T. pseudospiralis infection evoked the increase IgM immunoglobuline level in murine serum from days 5 to 20 p.i., i.e. during the intestinal phase of the infection (Fig. 1).

The low infective dose of Trichinella spiralis stimulated the production of specific $\mathrm{IgG}_{1}$ antibodies from day 20 p.i., with a sharp increase from day 45 p.i., but $T$. britovi infection induced the generation of specific $\operatorname{IgG}_{1}$ antibodies only on day 60 p.i. T. pseudospiralis infection did not affect the $\mathrm{IgG}_{1}$ production (Fig. 2).

The productions of $\mathrm{IgG}_{2 \mathrm{a}}$ and $\mathrm{IgG}_{2 \mathrm{~b}}$ were again earlier and more expressive after $T$. spiralis infection from day 45 p.i., on the contrary to $T$. britovi, where the antibody concentrations in serum were increased only on day 60 p.i. The low infective dose of $T$. pseudospiralis did not influence $\mathrm{IgG}_{2 \mathrm{a}}$ antibody response, but $\mathrm{IgG}_{2 \mathrm{~b}}$ immunoglobuline level started increasing from day 45 p.i., although with a lower intensity as in infections with encapsulating species (Figs. 3, $4)$.
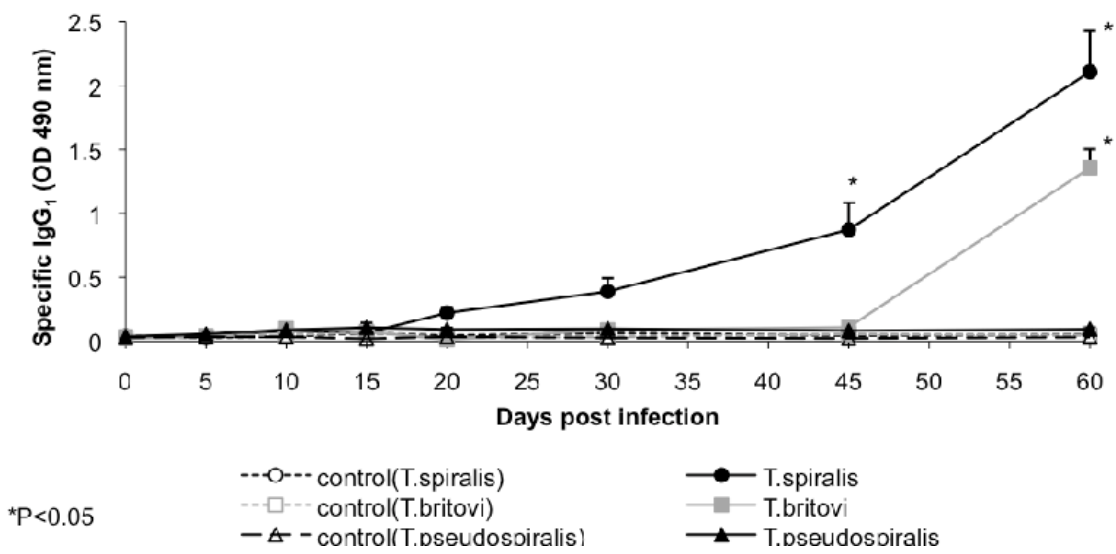

Fig. 2. Specific antibodies IgG1 in mice infected with 10 larvae of Trichinella spiralis, T. britovi and T. pseudospiralis. $*(P<0.05)$ statistically significant from control uninfected mice. 


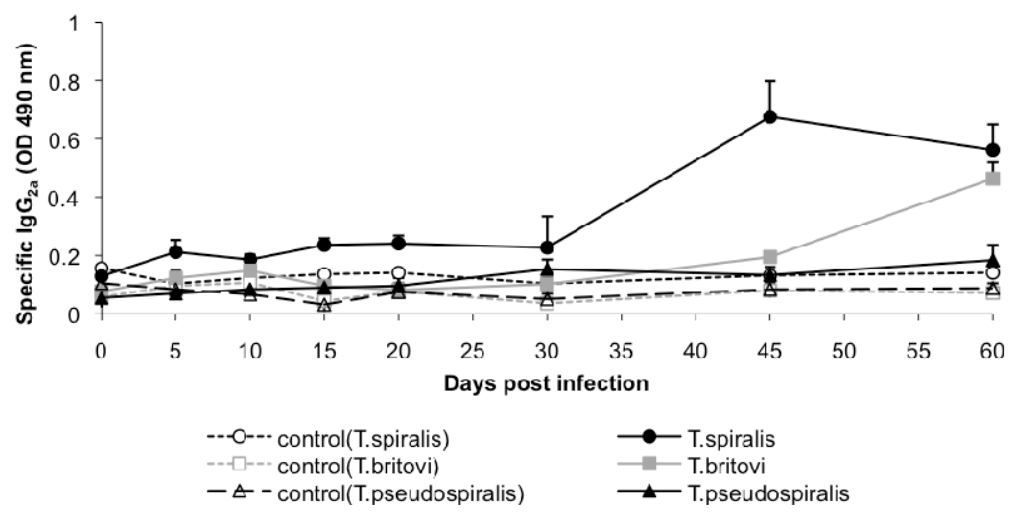

Fig. 3. Specific antibodies IgG2a in mice infected with 10 larvae of Trichinella spiralis, T. britovi and T. pseudospiralis.

Parasite burden - numbers of adults and muscle larvae (Figs. 5, 6)

Mice infected with the low dose of larvae absolutely eliminated parasite adults from the small intestine till day 20 p.i. in both encapsulating species. On day 15 p.i. the occurrence of $T$. spiralis adults in the intestine was sporadic $(0.13 \pm 0.35)$ in contrast to $T$. britovi, that were found in higher numbers of worms $(2.43 \pm 2.51) . T$. pseudospiralis adults were isolated from the small intestine also on day 20 p.i. $(0.62 \pm 0.74)$ (Fig. 5) there are detectable specific antibodies. This phenomenon is caused by excretory-secretory antigens from larvae settled in muscles (Pritchard, 1985; Li et al., 1999). Humoral immune response is important in the host defence against migrating newborn larvae. The absence of antigen on the cuticular surface of adult worms is in a sharp contrast to the findings described in muscle larvae, whose surface antigenicity is identical to that of stichocyte a-granules (Appleton et al., 1991). Therefore, no direct immune attack is likely to be exerted against adults. It has been suggested that the ef-

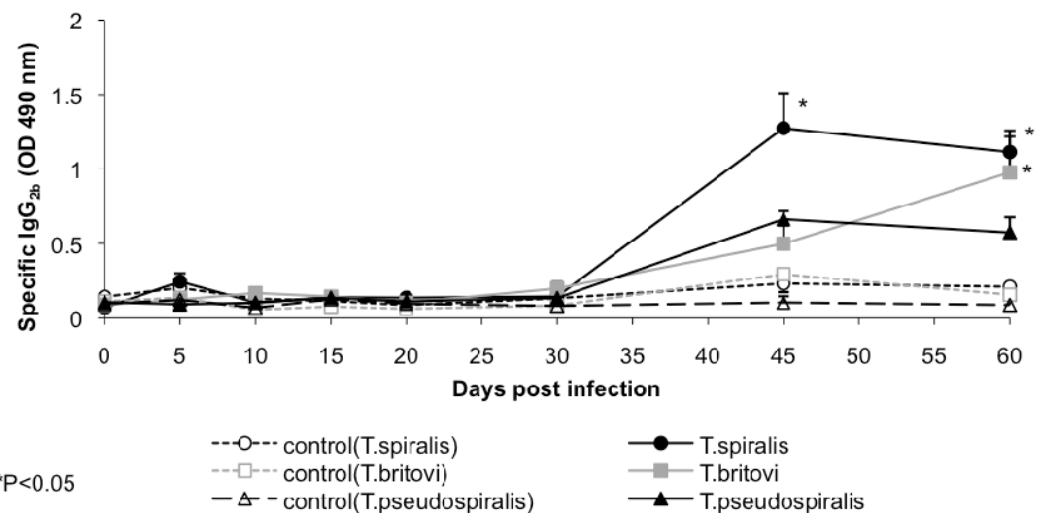

Fig. 4. Specific antibodies IgG2b in mice infected with 10 larvae of Trichinella spiralis, T. britovi and T. pseudospiralis. $*(\mathrm{P}<0.05)$ statistically significant from control uninfected mice.

Numbers of muscle larvae obtained after T. spiralis infection were the highest of all infections, what is related to the high reproductive capacity of this species. The maximum numbers of $T$. spiralis larvae were found on day 45 p.i. (3060 \pm 1859.1 larvae/mice), numbers of $T$. britovi and $T$. pseudospiralis peaked on day 30 p.i. (847.2 \pm 609.6 and $645.5 \pm 269.1$ larvae/mice, respectively) (Fig. 6).

\section{Discussion}

The presence of immune complexes in the vascular system is connected with the symptoms of trichinellosis at the beginning of the infection (Feldmeier et al., 1987). Later, when the parasite has been settled in muscles, neither Trichinella antigens nor immune complexes are detectable in blood, but fects of serum antibodies on worms may be indirect and that worm expulsion is the result of inflammatory processes in the intestines evoked by the infection (Wakelin \& Wilson, 1979).

An increased specific IgM antibody response, which is typical for acute infection, was not found in our experiment after the low infective dose of 10 larvae of $T$. spiralis and $T$. britovi. In comparison with control, neither seroconversion was detected. On the contrary, Reiterová et al. (2009) infected mice with 50 larvae of T. spiralis and recorded the seroconversion on day 30 p.i., but IgM antibody production overdrew a cut-off only a little. The low number of antigens might be bound into immune complexes. Contrary, T. pseudospiralis induced a higher level of specific IgM immunoglobulines during the intestinal phase till 


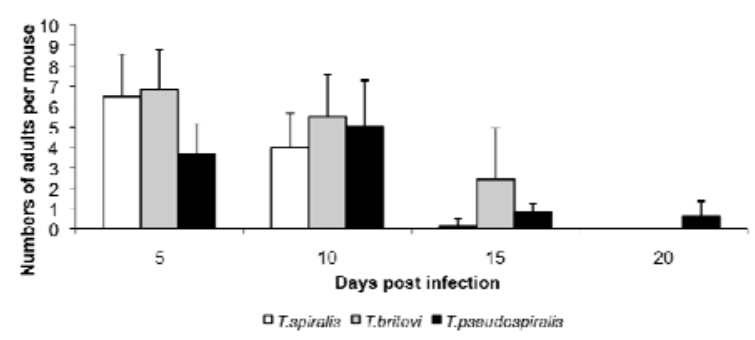

Fig. 5. Numbers of adults isolated from the small intestine of mice infected with 10 larvae of Trichinella spiralis, T. britovi and T. pseudospiralis.

day 30 p.i., what reflects the acute stage of the infection. An elevation of $\mathrm{IgG}_{1}$ accompanies the muscle phase of infection (Doligalska, 2000) and newborn larve are more sensitive in vitro to $\mathrm{IgG}_{1}$ in antibody-dependent cellular cytotoxicity (Moskwa, 1999). The low infective dose of 10 larvae of $T$. spiralis in our study stimulated $\operatorname{IgG}_{1}$ antibody production from day 20 p.i., with a significant elevation from day 45 p.i., but $T$. britovi infection induced the generation of $\mathrm{IgG}_{1}$ antibodies not until day $60 \mathrm{p}$.i. It correlates to $\mathrm{IgG}$ antibody response in outbred ICR mice after $T$. spiralis infection with low dose of 5 larvae (Reiterová et al., 2009). T. pseudospiralis infection did not show a positive specific $\mathrm{IgG}_{1}$ antibody response. The production of specific $\operatorname{IgG}_{2 \mathrm{a}}$ and $\operatorname{IgG}_{2 \mathrm{~b}}$ was again more expressive and earlier after $T$. spiralis infection from day 45 p.i. in contrast to $T$. britovi infection, where these antibodies increased their serum levels not until day 60 p.i. Only isotype $\mathrm{IgG}_{2 \mathrm{~b}}$ was detected in $T$. pseudospiralis infection on days 45 and 60 p.i., however at very low values in comparison to encapsulating Trichinella species.

Study by Furze and Selkirk (2005) compared antibody response in mice after $T$. spiralis a $T$. pseudospiralis infection with 500 larvae, whereby all classes of parasite-specific antibody were present in serum, but there were differences in the timing. Infection with $T$. spiralis notably induced greater amounts of $\operatorname{IgM}, \operatorname{IgG}_{1}, \operatorname{IgG}_{2 \mathrm{~b}}$ and $\mathrm{IgG}_{3}$ in serum during the muscle phases of infection.

The low infective dose of $T$. spiralis, T. britovi, and $T$. pseudospiralis in our study induced a late seroconversion in infected mice. Interspecies differences were found in immunogenicity of $T$. spiralis and $T$. britovi, which showed the similar trend, but varied in the intensity of the host antibody response. The species $T$. spiralis appeared to be more immunogenic and evoked more intensive and earlier specific antibody response of the host from day 45 p.i., when the antigen material had been markedly accumulated from the newborn and muscle larvae. As the reproductive capacity of $T$. britovi and $T$. pseudospiralis is lower in contrast to $T$. spiralis, the start of specific antibody response in $T$. britovi and $T$. pseudospiralis infections was recorded from day 60 p.i. The immune response to $T$. pseudospiralis infection suggested the biggest deviations. T. pseudospiralis adults persisted in the host small intestine for a longer time, untill day 20 p.i. Only mice infected with T. pseudospiralis reacted by low IgM antibody production during the intestinal phase, which was not observed in infections with encapsulating Trichinella species.

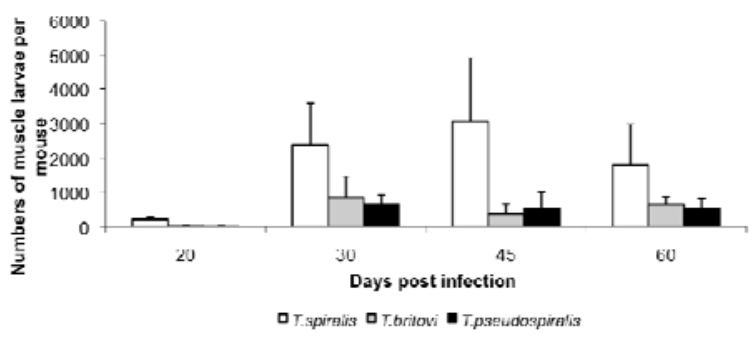

Fig. 6. Numbers of muscle larvae isolated from mice infected with 10 larvae of Trichinella spiralis, T. britovi and T. pseudospiralis.

All species T. spiralis, T. britovi and T. pseudospiralis are intracellular parasites of muscle cells, essentially with the same life cycle, which differ in only the fact, that complex "nurse cell" is or is not surrounded with a collagen capsule. The found differences in the host immune reactions to different Trichinella species in our study suggest that the immune response variations can be caused not only with distinctions of muscle larval L1 excretory-secretory antigens (Robinson et al., 2007; Milcheva et al., 2009), but also with parasite stages L2-4 and adults. Identification and characterization of species-specific proteins of development stages play an important role for understanding of mechanisms involved in the parasite-host interaction, which provide a longterm surviving for the parasite in the host organism.

\section{Acknowledgement}

This study was supported by the Slovak VEGA agency, grant No. 2/0071/08. The experimental protocols complied with the current Slovak ethic law.

\section{References}

ANDRADE, M. A., Siles-LuCAS, M., LÓPEZ-ABÁN, J., NoGALRUIZ, J. J., PÉREZ-ARELLANDO, J. L., MARTÍNEZ-FERNÁNDEZ, A. R., MurO, A. (2007): Trichinella: differing effects of antigens from encapsulated and non-encapsulated species on in vitro nitric oxide production. Vet. Parasitol., 143: 86-90

Appleton, J.A., Bell, R. G., Homan, W., VAN KnAPEN, F. (1991): Consensus on Trichinella spiralis antigens and antibodies. Parasitol. Today, 7: 190 - 192

APPLETON, J.A., UsACK, L. (1993): Identification of potential antigenic targets for rapid expulsion of Trichinella spiralis. Mol. Biochem. Parasit., 58: 53 - 62

Beiting, D. P., Bliss, S. K., Schlafer, D. H., Roberts, V. L., Appleton, J. A. (2004): Interleukin-10 limits local and body cavity inflammation during infection with musclestage Trichinella spiralis. Infect. Immun., 72: 3129 - 3137 BOLAS-FERNÁNDEZ, F. (2003): Biological variation in Trichinella species and genotypes. J. Helminthol., 77:111 - 118 Bruschi, F., TAssi, C., POZIO, E. (1992): Parasite-specific antibody response in Trichinella sp. 3 human infection: a one year follow-up. Am. J. Trop. Med. Hyg., 43: $186-193$ CAMPBELL, W.C. (1983): Epidemiology I. Modes of transmission. In CAMPBELL, W.C. (Ed.): Trichinella and Trichinosis. Plenum Press, New York (U.S.A.), pp. 425 - 444 
Candolfi, E., Franche, P., Liance, M., Houin, R., Vien, T. (1989): Detection of circulating antigen in trichinellosis by immunology. Comparative results in mice, rats and humans. Trichinellosis. Proceedings of the 7th International Conference on Trichinellosis, pp. 184-201

CuI, J., WANG, Z. Q., HAN, H. M. (2006): Congenital transmission of Trichinella spiralis in experimentally infected mice. Helminthologia, 43: 7 - 10

DoligalsKA, M. (2000): Immune response to Trichinella spiralis larvae after treatment with the anti-allergic compound ketotifen. Parasitol. Res. 86: 232 - 238

DZIEMIAN, E., MACHNICKA, B. (2000): Influence of Trichinella spiralis infective dose on the level of antibodies, circulating antigens and circulating immune complexes in rats. Helminthologia, 37: $59-66$

ElSE, K. J., FINKELMAN, F. D. (1998): Intestinal nematode parasites, cytokines and effector mechanisms. Int. J. Parasitol., 28: 1145 - 1158

FElDMEIER, H., FISCHER, H., BLAUMEISER, G. (1987): Kinetics of humoral response during the acute and the convalescent phase of human trichinosis. Zbl. Bacter. Mikrob. Hyg. Series A-Med. Microb. Inf. Dis. Virol. Parasitol., 264: $221-234$

Furze, R. C., SElKIRK, M. E. (2005): Comparative dynamics and phenotype of the murine immune response to Trichinella spiralis and Trichinella pseudospiralis. Parasite Immunol., 27: $181-188$

Hogaboam, C. M., Collins, S. M., Blennerhasset, M. G. (1996): Efectes of oral L-NAME during Trichinella spiralis infection in rats. Am. J. Physiol-Gastr. L., 271: $338-346$

KAPEL, C. M. O., GAMBLE, H. R. (2000): Infectivity, persistence, and antibody response to domestic and sylvatic Trichinella spp. in experimentally infected pigs. Int. J. Parasitol., 30: 215 - 221

KolodZIEJ-SobocinsKA, M., DvorožŇÁKovÁ, E., DZIEMIAN, E. (2006): Trichinella spiralis: Macrophage activity and antibody response in chronic murine infection. Exp. Parasitol., 112: 52 - 62

LI, C. K. F., Chung, Y. Y. Y., Ko, R. C. (1999): The distribution of excretory/secretory antigens during the muscle phase of Trichinella spiralis and T. pseudospiralis infections. Parasitol. Res., 85: 993 - 998

LI, C. K. F., KO, R. C. (2001): Inflammatory response during the muscle phase of Trichinella spiralis and T. pseudospiralis infections. Parasitol. Res., 87: 708 - 714

Machnicka, B., Prokopowicz, D., Dziemian, E., KoŁoDZIEJ-SOBOCIŃSKA, M. (2001): Detection of Trichinella spiralis antigens in urine of men and animals. Wiad. Parazytol., 47: 217 - 225

Milcheva, R., Petkova S., BabÁL, P. (2009): Detection of O-glycosylated proteins from different Trichinella species muscle larvae total extracts. Helminthologia, 46: $139-144$ Miterpáková, M., Hurníková, Z., Antolová, D., DUBINSKÝ P. (2009): Endoparasites of red fox (Vulpes vulpes) in the Slovak Republic with the emphasis on zoonotic species Echinococcus multilocularis and Trichinella spp. Helminthologia, 46: 73 - 79

MOlOnEY, A., DENHAM, D. A. (1979): Effects of immune serum and cells on newborn larvae of Trichinella spiralis. Parasite Immunol., 1: 3 - 12

Morales, M. A. G., Mele, R., Sanchez, M., Sacchini D., DeGiacomo, M., PozIO, E. (2002): Increased CD8(+)-Tcell expression and a type 2 cytokine pattern during the muscular phase of Trichinella infection in humans. Infect. Immun., 70: $233-239$

MorgAN, U.M. (2000): Detection and characterisation of parasites causing emerging zoonoses. Int. J. Parasitol., 30: $1407-1421$

MoskwA, B. (1999): Trichinella spiralis: in vitro cytotoxicity of peritoneal cells against synchronous newborn larvae of different age. Parasitol. Res., 85: 59 - 63

MurRell, K. D., BRUSCHI, F. (1994): Clinical trichinellosis. Prog. Clin. Parasitol., 4: $117-150$

PARALIČOVÁ, Z., KINČEKOVÁ J., SCHRÉTER, I., JARČUŠKA, P., Dubinský JR. P., PorubČIn, Š., PAVlinovÁ, J., KrisTIAN, P. (2009): Outbreak of trichinellosis in eastern Slovakia. Helminthologia, 46: 209 - 213

PRITCHARD, D. I. (1985): Antigen production by encysted muscle larvae of Trichinella spiralis. J. Helminthol., 59: 71 $-77$

ReITEROVÁ, K., Dubinský, P., Klimenko, V. V., TOMAŠOVIČOVÁ, O., DVOROŽŇÁKOVÁ, E. (1999): Comparison of Trichinella spiralis larva antigens for the detection of specific antibodies in pigs. Vet. Med-Czech., 44: $1-5$ ReiterovÁ, K., ANTOlOVÁ, D., HurníKOVÁ, Z. (2009): Humoral immune response of mice infected with low doses of Trichinella spiralis muscle larvae. Vet. Parasitol., 159: $232-235$

Robinson, M. W., Grieg, R., BeAttie, K. A., LAmont, D. J., ConNolly, B. (2007): Comparative analysis of the excretory-secretory proteome of the muscle larva of Trichinella pseudospiralis and Trichinella spiralis. Int. J. Parasitol., 37: $139-148$

TuRČEKOVÁ, L., BOROŠKOVÁ, Z., TOMAŠOVIČOVÁ, O., REITEROVÁ, K., KINČEKOVÁ, J. (1997): Immunochemical analysis of larval antigens of Trichinella spiralis and $T$. pseudospiralis. Helminthologia, 34: 241 - 243

WAKELIN, D., GOYAL, P. K. (1996): Trichinella isolates: parasite variability and host responses. Int. J. Parasitol., 26: $471-481$

WAKELIN, D., WILSON, M. M. (1979): Trichinella spiralis: immunity and inflammation in the expulsion of transplanted adult worms from mice. Exp. Parasitol., 48: $305-312$

WANG C. H., BELL, R. G. (1988): Antibody-mediated invivo cytotoxicity to Trichinella spiralis newborn larvae in immune rats. Parasite Immunol., 10: 293 - 308 